\title{
Desalination for securing water productivity in an intensively used coastal aquifer (Campo de Dalías, Spain)
}

\author{
AURÉLIEN DUMONT ${ }^{1,2}$, ELENA LÓPEZ-GUNN ${ }^{3}$, ESPERANZA MONTERO \\ GONZÁLEZ ${ }^{1}$ \& M. RAMÓN LLAMAS ${ }^{1,2,4}$ \\ 1 Geology Faculty, C/ J.A. Novais, 12, 28040 Madrid, Spain \\ adumontv@gmail.com \\ 2 Water Observatory of the Botin Foundation, Madrid, Spain \\ 3 I-CATALIST, Madrid, Spain \\ 4 Spanish Royal Academy of Sciences, Madrid, Spain
}

\section{INTRODUCTION}

The Campo de Dalías aquifer is a coastal aquifer located in the southeast Spain (Andalucia). Since the 1960s, the area has experienced a spectacular economic development based on the intensive use of groundwater for the irrigation of greenhouse crops, becoming one of the world's largest areas under greenhouses. This development, however, coincided with a rising groundwater demand from cities and tourism. The resulting fall in groundwater levels and seawater intrusion jeopardizes water security for the local economy based on intensive groundwater use. To remediate this situation, it is expected that from 2014-2015, part of the supply will be obtained from desalinated seawater, so as to reduce withdrawals. The main aims of this study are: first, to detail the water footprint in Campo de Dalias, and its productivity, with a particular focus on agriculture; second, review the process of seawater intrusion; and, finally, analyse the role of desalination as a solution to ensure water security for the multiple water uses and implications for cost recovery in the context of the European Union Water Framework Directive (WFD).

\section{WATER ACCOUNTING AND PRODUCTIVITY}

The agriculture of the Campo de Dalías is exclusively dedicated to the production of fruits and vegetables in greenhouses that virtually cover all the arable land in the area (16 $500 \mathrm{ha})$, thus the name of 'a sea of plastic'. Water accounting is based on the water footprint (WF) method. Peppers, tomatoes, cucumbers, eggplants and zucchinis account for $85 \%$ of the WF of the agricultural production that reached $103 \times 10^{6} \mathrm{~m}^{3}$ in the 2012. Watermelon, melon and green beans

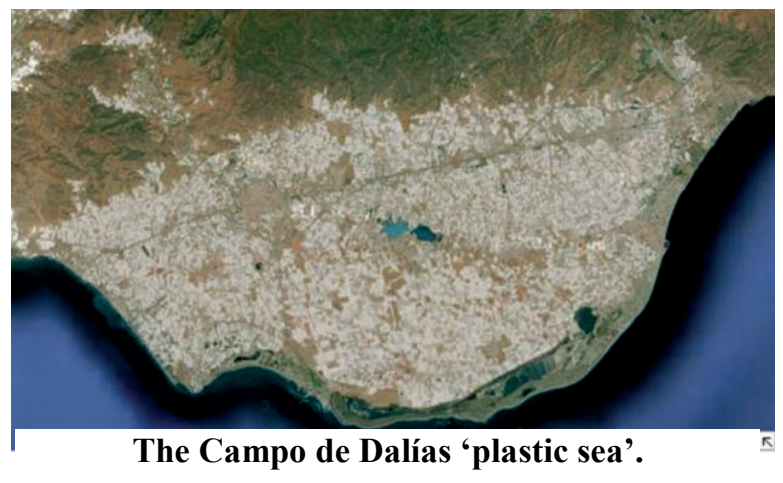
account for the rest. Land and water productivities are very high: $62000 € /$ ha and $10 € / \mathrm{m}^{3}$, respectively. For comparison, the typical productivity in other groundwater irrigated areas in Spain are $3000 € /$ ha and $1.5 € / \mathrm{m}^{3}$. This high productivity is mainly due to the intensive production in greenhouses that allows for two crop cycles per year (the same crop or two different crops), or a long cycle of production. Other determinant factors are the climate, with mild temperatures making it possible to produce during winter when there are few competitors for fresh vegetables; access to local or external inputs such as groundwater and fertilizers; and an efficient cluster organization.

Groundwater is also withdrawn for urban use and tourism and the total withdrawals are estimated to have reached $130 \times 10^{6} \mathrm{~m}^{3}$ in 2012 , with an average recharge of $80 \times 10^{6} \mathrm{~m}^{3}$. An additional $10 \times 10^{6} \mathrm{~m}^{3}$ are obtained from surface water and $5 \times 10^{6} \mathrm{~m}^{3}$ from the Almería desalination plant. 


\section{SEAWATER INTRUSION: IMPLICATIONS FOR FUTURE WATER SECURITY}

The geology of the Campo de Dalías Aquifer is characterized by a series of faults generating complex underground flow paths. An upper aquifer system and a lower aquifer system can be distinguished: the upper aquifers were the original source of groundwater but have been progressively replaced by the lower aquifers as the main water source. For the majority of the coastline, there is no direct contact between the sea and the lower aquifers. In the North-Eastern Lower Aquifer, the direct contact with the sea generated seawater intrusion that made it necessary to sharply reduce withdrawals. The Western Lower Aquifer (WLA) is also indirectly in contact with the sea through a small aquifer, but this relative isolation implied that seawater inflows were rather small considering the freshwater stock, allowing pumping to continue for years, with an unusual situation where groundwater levels are up to $48 \mathrm{~m}$ below sea level (Domínguez-Prat 2013). In this context, repeated warnings of seawater intrusion were seen as pessimistic, since pumping could continue, which put into question the hydrogeological expertise.

However, pumping must now be reduced to levels well below recharge in the WLA to limit future seawater intrusion because there is a 'competition' between seawater intrusion and freshwater recharge to recover the depleted stock. Thus 'there is no free lunch', the delayed effects of past intensive pumping mean that future water security for the whole area could be jeopardised. Seawater water might even get trapped in the aquifer, preventing its use in the future.

\section{DESALINATION: AN OPTIMISTIC SOLUTION?}

To address dropping groundwater levels and potential seawater intrusion, a desalination plant is expected to enter into service in 2015 to supply $27 \times 10^{6} \mathrm{~m}^{3}$ to the area. The project has received public subsidies partly from the EU as a measure to achieve the Campo de Dalias groundwater body's 'good status' under the EU WFD. However, if seawater intrusion is viewed as a contaminant, this funding would go against the 'polluter pays' principle.

Regarding cost recovery, urban users are required to pay more because they will benefit from desalinated water. Meanwhile, prices paid by farmers are lower than the estimated cost for desalinated water. Yet desalinated water and groundwater could be seen as adding up to a single resource pool for water provision to which all users have to contribute to costs according to transparent rules, which include responsibility for the current state of the aquifer. Under this view there is a cross-subsidy from urban users and tourism to agriculture. Desalination, its costs and impacts, should in fact be balanced against the benefits derived by the uses. At the moment, desalination is justified by the 'general interest' all users would have in aquifer recovery to good status. However, considering the level of water productivity, applying cost recovery would imply raising the cost of water by $0.20 € / \mathrm{m}^{3}$, representing $2 \%$ of agriculture water productivity.

One reason why the authorities might be reluctant to apply cost recovery is because the cheaper cost of groundwater supply means users would keep using groundwater, despite agreements to use desalinated water. Therefore, while in theory desalination at full capacity would balance recharge and groundwater withdrawals, the precedent set by an already existing desalination plant in Almería is illustrative since it is not used at full capacity. Thus the solution posed to the problem of aquifer recovery and marine intrusion in Campo de Dalias - through desalination - does not bode well. The lack of transparent decision-making combined with high energy prices, among other issues, raises important questions of the feasibility of desalination as the simple solution to a complex problem. The plan, however, is an attractive solution when there are socially and politically difficult decisions and actions to be taken to reduce (partly illegal) groundwater withdrawals. Questioning the drivers and gradually changing the incentives has not been the main focus, thus the opportunity offered by the preserved access to the groundwater stock despite marine intrusion to evolve toward a less water-intensive economy has been missed.

\section{REFERENCE}

Domínguez-Prat, P. (2013) Avance en el conocimiento de los acuíferos del Sur de Sierra de Gádor - Campo de Dalías, mediante los trabajos de la fase inicial del Programa de investigaciones de apoyo a su protección - regeneración Abril de 2013. VI Seminario Técnico Agronómico Cajamar, Almería, 25/04/2013. 